\title{
Legal Protection Toward Famous Brand as an Intangible Asset in Indonesia
}

\author{
I Made Delon Mahayana ${ }^{1}$, I Nyoman Putu Budiartha ${ }^{2}$ and I Nyoman Sujana ${ }^{3}$ \\ \{mahayana.delon@gmail.com, putu.budiartha59@gmail.com and Nyoman.sujana@yahoo.co.id\} \\ Universitas Warmadewa, Denpasar, Bali - Indonesia
}

\begin{abstract}
This study examines the legal protection based on positive law on the registration of famous brands in Indonesia. We carried out this study using statue and conceptual approaches. The study data were collected through library research, i.e. collecting the theories and legal protection provisions for brands and specifically for famous brands. Results show that legal provisions for famous brands protection in Indonesia are still vague, especially as stipulated in the Republic of Indonesia Law Number 20 of 2016 concerning Trademarks and Geographical Indication. From positive law aspect, registration of famous brands is protected by preventive and repressive measures. In Indonesia, an Independent institution functioning to inventory and determine a database and criteria for a brand is required. In addition, the Government Regulation after the issuance of Law Number 20 of 2016 concerning Trademarks and Geographical Indications and between the Government and the community needs to be formulated and enforced.
\end{abstract}

Keywords: Famous brand; intangible asset; legal protection

\section{Introduction}

The development of trade in goods and services in Indonesia in the past few years has experienced a significant increase due to the development of information technology and means of transportation which have led to very rapid development in the trade sector, both goods and services. The trend of increasing trade flows of goods and services continues in line with national economic growth. In connection with law, brand as an important element of trade sector is one of the subjects protected by law in many countries $[1,2]$. In Indonesia, the Law governing the brands is stipulated in Law Number 20 of 2016 concerning Trademarks and Geographical Indications. A brands is a part of the intellectual property system that has significant influence on the commercial field functioning as an identifier and differentiator of a product from others traded $[3,4,5]$. The brand of a product or item has a role in drawing the attractiveness of the purchasers to an item, product or even service.

Brands as one of human intellectual works that have a close relation with economic and trade activities play a crucial important role. With the increasing flow of globalization in all sectors, including the sector of trade of goods and services, trade in goods and services has ignored borders of the country, so that regulations in the field of Intellectual Property Rights (IPR), including product brands, must be adequate and effective since Indonesia has become a member of the World Trade Organization (WTO) through Law No. 7 of 1994 concerning Establishment of Ratification of the World Trade Organization on November 2, 1994, which contains the Annex Agreement on Trade Related Aspects of Intellectual Property Rights 
(Agreement on TRIPs) [6]. Regarding the violation of the IPR, its development is also much influenced by its nature as an intangible right [7]. It is not easy for people to understand why a person cannot enjoy complete freedom of his property, including to obtain economic benefits from them. A person can ask about the rights born of his actions on an object (such as purchasing goods). The owner of the object may ask, "Why don't I use the item that I have bought to make money or profits from the amount of money I have spent on the purchase?"

A brand of a product can be briefly said to be a sign used by employers or producers to distinguish their products from those of others for similar goods so that the public as consumers are not be made fooled about the origin of goods produced or traded [8]. Based on Law of the Republic of Indonesia No. 20 of 2016, a brand obtains legal protection if it is already registered in the General Register of Brand, so that the Brand Owner has the exclusive rights to the brand and this is in accordance with the principles adopted by Republic of Indonesia Law No. 20 of 2016, namely constitutive system (first to file system).

Unfortunately, entrepreneurs or producers of a product have not yet enjoyed the distinct advantages of their product brands as a result of a lack of understanding of the legal rules regarding brands that essentially provide commercial benefits, in addition to protective advantage. Additionaly, some conducted legal studies on the world of trademark have not revealed specifically what and how the brand of a product must be protected form legal side as a form of intellectual property. Based on this, the present study examines the formulation of legal provisions regarding famous brands and reveals forms of legal protection for famous brands in positive law in the brand registration system in Indonesia.

The method used to examine legal phenomena in this paper is the normative legal method, using the statue approach and conceptual approach. Data collected by library research. The data used are articles of Indonesian law that regulate brands and brand protection, especially famous brands. Data were analyzed descriptively, i.e. outlines the explanations related to Indonesian laws governing them, interpreting those meanings based on the essence of legal science and empirical facts in the trade sector, and comparing the results of these analyzes with the results of previous studies. in addition, a review of the grammatical aspects of the brand discussion is done in order to obtain an initial picture of a famous brand.

\section{Results and Discussion}

\subsection{Indonesian Legal Formulation Regarding the Determination of a Famous Brand}

A well-known brand has a reputation and has high marketing base. This brand is the choice for every consumer anywhere. The percentage of sales is high in every corner of the world and is a valuable wealth asset that can bring huge profits to its owners [9]. However, at the same time, it can cause harm to the owner and on the other hand, it is very profitable for other parties with bad intentions by imitating or falsifying with very low quality [10]. Protection of famous brands is not only given to similar goods or services, but also to goods or services of different type.

Topics related to famous brands are still discussed because until now and thus there has been no concrete definition of a famous brand [11][8][12][13] [14]. However, the guidelines issued by WIPO (World Intellectual Property Organization), essentially, concern the factors in considering whether a brand is well-known or not. The things that must be considered include:

a. The level of knowledge or recognition of the brand in the public sector concerned.

b. Period, range and geographical area of brand use 
c. The period, range and geographical area of brand promotion, including advertising and publicity as well as presentations at exhibitions of the brand's goods or services.

d. The period and geographical area of each registration and each registration application reaches a level that reflects brand use or recognition.

e. Records from successful law enforcers of the rights attached to the brand to a level where the brand is recognized as a well-known brand by the competent authority

f. Values related to the brand. The criteria for a well-known brand are based on public knowledge, the determination is also based on the reputation of the brand concerned that has been obtained due to promotions carried out by the owner and accompanied by proof of registration of the mark in several countries [15].

The criteria for well-known brands are based on the general knowledge of the community, also based on the reputation of the brand concerned that has been obtained due to promotions carried out by the owner and accompanied by proof of registration of the brand in several countries.

In the United States, in Article 43 (c) (1) of the Lanham Act (Trademark Act), the determination of brands has distinguishing and well-known properties; the court can consider factors such as [16]:

a. The degree of inherent nature or the distinguishing nature of the brand;

b. The period and scope of the use of the brand relating to the goods and services of the brand used;

c. The duration and scope of advertising and publicity of the brand;

d. The geographical scope of the trading area where the brand is used;

e. Trade network of goods and services of the brand used;

f. The degree of recognition of the brand from the trading arena and the trade network of the brand owner and the prohibition against people on the use of the brand are carried out;

g. General nature and scope of the use of the same brand by third parties;

h. The existence of the registration of the mark is based on the Act dated March 13, 1981 or the Act dated February 20, 1905 or first registration.

In spite of having had regulated the terms of the brand in such a way, in practice some problems in brand inspection often arise [17]. One of the most prominent problems is related to "equality". In the provisions of article 6 paragraph (1) letter a mentioned:

"that the trademark application must be rejected by the Director General of Investment Information if the brand has similarity in principle or in whole with the brand of another party that has been registered in advance for similar goods and or services How to determine whether there is a brand equality or not."

The overall equation of the element is a standard for determining the existence of an equation that corresponds to a similar entirentist doctrine [2]. In this case the brand requested to be registered is a copy or reproduction of another person's brand. So that something can be called a copy or reproduction of someone else's brand so that it can be qualified to contain the overall equation, at least must meet the requirements: (1) There are equal elements of the brand as a whole; (2) Equation of type or production and class of goods or services; (3) Equation of region and company segment; (4) Equations of ways and behavior of use; (5) Equation in the way of maintenance; and (6) Equation on the marketing channels.

The above conditions are cumulative, so that all equations must be determined must be fulfilled. However, the standard of determination based on this teaching is considered too rigid and cannot protect the interests of brand owners, especially for well-known brands. The equation in principle is as stipulated in the explanation of Article 6 paragraph (1) of Law No. 20 of 2016 concerning Trademark and Geographical Indication, namely that what is meant by 
equality is basically the similarity caused by the presence of prominent elements between one brand and another brand, which can give the appearance of equality in the form (painting or writing ), the method of placement (i.e. elements arranged in such a way as to create the same impression as the brand of another person's product), the meaning and combination of elements or similarities in the speech in the brands. The definition of equality regulated in this explanation is in accordance with the doctrine of "nearly resembles" [2], which considers a brand to have similarities in common with other people's brands if it is identical or nearly resembles other people's brands, which can be based on the similarity of the image, word order, color or sound. Based on the description above, this is in accordance with the Law Certainty theory which contains two senses, namely first, the existence of general rules makes individuals know what actions are or should not be done, and second, in the form of legal security for individuals from government abuse because with the general rules, individuals can find out what the state can charge or do with individuals [18]. Legal certainty is not only in the articles in the law, but also consistency in the judge's decision between one decision and the other judge's decision for a similar case that has been decided.

A brand necessarily has a special characteristic that is identical to its personality and indeed born new, it is not a brand that is renewed or something that fails to improve is better. The use of a brand is not only limited to making a profit. Brands have other objectives that can not only be seen from an economic perspective [19]. Brands also have a role to facilitate the trading of goods or services to carry out development [5]. Therefore, protection of the brand is needed so as not to make plagiarism activists more aggressively with dirty practices. That, because basically brand protection is not only for the sake of brand owners but also for the benefit of the wider community as consumers.

Plagiarism activists do not only occur in several aspects in Indonesia. Problems regarding brand protection also occur in various countries [20]. The benefits obtained in a way that is not difficult to encourage a brand to emulate or ride famous like an artist. Imitation of a wellknown brand to become rampant is indeed based on "bad faith". Solely the purpose is materially or financially oriented, making a profit by joining the popularity of a brand. Such treatment is indeed not and should not be appropriate to obtain legal protection. Protection of famous brands can be done in various ways. In addition to the brand owner's response and initiative, it can also be carried out by the brand office by refusing requests for registration of the same or similar brands with well-known brands.

There are a number of things to note, namely: (1) Not setting definitions and criteria for famous brands; (2) Rejection or cancellation of a brand, or prohibition on the use of a brand that is a reproduction, imitation or translation that can be misleading of an item or service that is the same or similar if the laws of the country regulate or request a party concerned; and (3) The cancellation claim can be submitted at least for 5 years from registration, but there is no time period if the registration is done in bad faith.

Therefore, the formulation of a well-known brand must be clear in the determination of the criteria so that it does not intersect with the registration of a new brand that is applied so that in addition to harming registered brands, it will bring a loss to the new brand whose application for registration will apply. Thus, regarding the explanation of article 21 of Law No. 20 of 2016 concerning Trademarks and Geographical Indications, its provisions must provide more definitely strong clarity about the criteria intended by a Famous Brand, either in the period of use or other things that can explain the description of a famous brand. In addition, in Article 6 the bus of the Paris Convention (1967) applies, mutatis mutandis, for services. In determining whether a trademark is well-known, members must consider 
trademark recognition in the relevant sector of society, including knowledge in the member concerned that has been obtained as a result of trademark promotion.

\subsection{Legal Protection toward Well-Known Brands in Indonesia Positive Law in the Brand Registration System in Indonesia}

In the Implementation of Law No. 20 of 2016 concerning Trademarks and Geographical Indications, it is stipulated that brand registration is very important in order to provide legal protection to holders of rights to the brand. Brand registration using a constitutive system (first to file) guarantees legal certainty for holders of brand rights, but until now the brand registration system with the concept of first to file in Indonesia has not effectively created harmony in guaranteeing fairness and benefit, because there are still many brands - brands registered not by the actual brand owner. Referring to Law No. 20 of 2016 concerning Trademarks and Geographical Indications, what is meant by a brand is a sign in the form of images, names, words, letters, numbers, color arrangements, or combinations and those elements which have distinguishing features and are used in trading activities goods or services. In its notion, as revealed by Setiono, legal protection is an action or effort to protect the public from arbitrary acts by the authorities that are not in accordance with the rule of law, to create order and peace so as to enable humans to enjoy their dignity as humans [21]. In line with the notion, Muchsin's concept is that legal protection is a matter that protects legal subjects through applicable laws and regulations and is forced to implement it with a sanction.

A legal protection can be divided into two, namely: First, preventive legal protection: protection provided by the government with the aim of preventing before the occurrence of violations. This is contained in laws and regulations with the intention of preventing a violation and providing signs or limitations in carrying out obligations. Second, repressive legal protection: legal protection in the form of sanctions such as fines, imprisonment, and additional penalties given when a dispute has occurred or a violation has been committed [22].

Hence, legal protection is any form of effort to protect human dignity and recognition of human rights in the field of law. The principle of legal protection for the people of Indonesia comes from Pancasila and the concept of the rule of law. Both sources prioritize recognition and respect for human dignity. Meanwhile, the means of legal protection are of two forms, namely the means of preventive and repressive legal protection.

Preventive Legal Protection by the Government: In the case of Preventive Legal Protection carried out by the government through its state equipment, it is conducted by giving an appeal about the importance of an Intellectual Property right to be registered in order to obtain definite legal protection, namely protection provided by the government with the aim of preventing prior violations. In this case the government provides preventive protection through appeals to trade centers and also through socialization about the importance of protecting intellectual property. This is contained in legislation with the intention of preventing a violation and providing signs or limitations in carrying out obligations.

Repressive Legal Protection by the Government: Repressive legal protection carried out by the government aims to follow up all complaints of the owners of intellectual property rights to obtain real legal protection. Repressive legal protection is the final protection in the form of sanctions such as fines, imprisonment, and additional penalties given when a dispute has occurred or a violation has been committed.

\section{Conclusion}


Starting from the background of the problem, the formulation of the problem, and the purpose of the study, there are several conclusions that can be drawn from the results of this study. Firstly, the formulation of the provisions of a famous brand is still vague as stated in the Republic of Indonesia Law Number 20 of 2016 concerning Trademarks and Geographical Indications. The indication is for a brand to be well-known, it requires an accredited and independent institution in its determination and classification so that the submission of a new brand application must be able to refer to the famous brand database in the Independent Institution by referring to the TRIPS (Trade-Related Aspects of Intellectual Property) Rights). Second, the efforts made by the government in providing legal protection for well-known brands in positive law in the Indonesian brand registration system are manifest in two forms, namely preventive protection and repressive protection. Based on the results of this study, we recommend several things. The Indonesian government needs to immediately form an independent institution tasked with inventorying and determining a data base and criteria for a brand that is said to be famous so that people who want to apply for a brand can get official information about any brand that has been registered as a well-known brand, so that later there will be brand issues that intersect with well-known brands that already exist. In addition, the Government Regulation after the issuance of Republic of Indonesia Law Number 20 of 2016 concerning Trademarks and Geographical Indications and between the Government and the public needs to be issued to provide protection for brands that are synergistic so that there is no gap. In other words, the government regulation is expected to narrow the circulation of counterfeit brands so that the protection and benefits from the issuance of legislation, especially the Republic of Indonesia Law Number 20 of 2016 can be felt by the public and the government can be more assertive in providing protection for the rights to Intellectual Property (IPR) as well as possible.

\section{References}

[1] Fangfei Wang, F.: Domain names management and legal protection,” Int. J. Inf. Manage, vol. 26 (2). pp. 116-127 (2006)

[2] Kim, W, G.: Branding, brand equity, and brand extensions, Sixth Edition. Elsevier Ltd (2008)

[3] Louw, A.: What intellectual property lawyers can learn from Barbra Streisand, Sepp Blatter, and the 'Coca-Cola cry-baby': dealing with 'trademark bullying' in South Africa, Potchefstroom Electron. Law J. vol. 16 (5). pp. 1-42 (2013)

[4] Batzer, B, Cwik, J and Carrera, G.: Intellectual property considerations, Dev. New Funct. Food Nutraceutical Prod. pp. 109-121 (2016)

[5] Deorsola, A, B, Martins Ribeiro Leal, M, C, Cavalcante, M, D, Schmidt, I, J and Braga, E, J.: Intellectual property and trademark legal framework in BRICS countries: A comparative study, World Pat. Inf. vol. 49. pp. 1-9 (2017)

[6] Direktorat Jenderal Hak Kekayaan Intelektual, Kementerian Hukum dan Hak Asasi Manusia Republik Indonesia, in Buku Panduan Hak Kekayaan Intelektual, Tangerang (2011)

[7] Sas, B, Jacobs, P and De Vocht, S.: Trademarks, Intellect. Prop. Assess. its Financ. Value, pp. 61-80 (2014)

[8] Hemnes, T, M, S.: From experience. Perspectives of a trademark attorney on the branding of innovative products, J. Prod. Innov. Manag. vol. 4 (3) pp. 217-224 (1987)

[9] Reuben, R, C and Reuben, R, C.: Trademark And Patent Law What Â€Tm S New | N Intellectual Property Business Is Booming And Patent In Trademark, vol. 79 (1). pp. $72-77$ (2014.)

[10] Purba, A, Z, U.: Hak Kekayaan Intelektual Pasca TRIPs. Bandung: PT. Alumni (2005)

[11] Chudnovsky, D.: Foreign trademarks in developing countries, World Dev. vol. 7 (7) pp. $663-$ $682(1979)$

[12] Ramello, G, B.: What's in a sign? Trademark law and economic theory, J. Econ. Surv. vol. 20

(4). pp. 547-565 (2006) 
[13] Blackett, T.: Trademark Valuation - What â€TM s Happening Now ? (2008)

[14] Fink, C, Helmers, C and Ponce, C, J.: Trademark squatters: Theory and evidence from Chile, Int. J. Ind. Organ. vol. 59. pp. 340-371 (2018)

[15] Harahap, Y.: Tinjauan Merek Secara Umum dan Hukum Merek di Indonesia Berdasarkan Undang-Undang No. 19 Tahun 1992. Bandung: PT. Citra Aditya Bakti (1996)

[16] Gautama, S and Winata, R.: Pembaharuan Hukum Merek Indonesia (Dalam Rangka WTO, TRIPS). Bandung: PT Citra Aditya Bakti (1997)

[17] Spatareanu, $M$ and Washington, B.: Trade: Biases in International Data Tell Us? What Do Trademark Registration, vol. 141 (1). pp. 79-103 (2012)

[18] Lemper, T, A.: Five trademark law strategies for managing brands, Bus. Horiz. vol. 55 (2) pp. 113-117 (2012)

[19] Hammond, G.: Legal Protection of Ideas, Comput. Law Secur. Rep. no. JULI-AUGUSTUS, pp. $155-161(1992)$

[20] Wilke, R and Zaichkowsky, J, L.: Brand immitation and Brand Equity, Bus. Horiz.

[21] Setiono.: Rule of Law (Supremasi Hukum). Magister Ilmu Hukum Program Pascasarjana Universitas Sebelas Maret (2004)

[22] Muchsin.: Perlindungan dan Kepastian Hukum bagi Investor di Indonesia. Surakarta: Universitas Sebelas Maret (2003) 